\title{
Does Absenteeism Affect Academic Performance? An Insight from UK-Based Medical Students [Letter]
}

This article was published in the following Dove Press journal:

Advances in Medical Education and Practice

\section{Rishikesh Gandhewar (C) \\ Kalyan Vemulapalli (iD}

Faculty of Medicine, Imperial College London, London, UK
Correspondence: Rishikesh Gandhewar; Kalyan Vemulapalli

Faculty of Medicine, Imperial College London, London, UK

Tel +44 78I 793 575I; +44 750 24I 7908

Email kvv16@ic.ac.uk; rg2316@ic.ac.uk

\section{Dear editor}

Latif Khan et $\mathrm{al}^{1}$ have highlighted absenteeism as an important issue amongst medical schools. Although the article originates from Pakistan, the authors state that this is a worldwide issue. The study focusses on lecture attendance. However, worldwide several teaching methods are employed including problem-based learning, team-based learning and video-recorded technologies. As UK medical students, we offer an alternative perspective on the conclusions of the study.

We acknowledge several strengths of the study; however, we would like to share a few reflections. Given the range of teaching methods, it would have been appropriate to define the exact parameters of a lecture and therefore disclose the employment of other methods. We feel that this would provide a more holistic overview of student timetables, including total contact hours per week. Consequently, the relative importance of attending lectures compared to attending other teaching sessions for accruing appropriate skills and knowledge is unknown. If teaching occurred outside of lectures, the degree of absenteeism would not be accurate. Conversely, if solely lectures were employed, the conclusions drawn from this study may not be translatable to the rest of the world where other teaching methods are in place.

Furthermore, although the study reaffirms the issue of absenteeism and suggests potential reasons, we feel it would have been more beneficial to determine reasons for absenteeism within the sample. This would be of use to identify student motivations and issues. Additionally, absenteeism may be a confounder for an underlying cause, such as mental health which has been shown to affect both academic performance ${ }^{2}$ and attendance. ${ }^{3}$ Therefore, enforcing mandatory attendance (as implied by the authors to be beneficial) could have a negative impact on these students. Major causes identified can then be addressed and rectified in order to improve both attendance and academic performance.

The authors raise an important point of an increasing use of video-captured lectures and online self-learning resources. Alongside alternative teaching methods, we would like to further expand upon their impact on our learning experience. We feel the authors exaggerate the value of lectures, stating that students who do not attend lectures do not "foster a positive learning environment", "[accelerate] teamwork abilities" or increase "self-confidence". We find these claims to be overstated with a lack of supporting literature or poorly related references. From our experience, team-based learning and interactive group work better developed these skills. 
Furthermore, several studies show that video-recorded lectures are as effective as live lectures ${ }^{4}$ with added advantages of being able to seamlessly pause, rewind, research and resume the lecture.

To conclude, we acknowledge the correlation between absenteeism and academic performance identified by this study but believe a few alterations would allow for more concrete and valuable conclusions to be drawn. This includes detailing student timetables and exploring alternative teaching methods. We felt it would be of more value to investigate causes for absence and later stratify for these to reduce confounding bias. Future studies could achieve this through student-questionnaires or semi-structured interviews.

\section{Disclosure}

The authors report no conflicts of interest in this communication.

\section{References}

1. Latif Khan Y, Khursheed Lodhi S, Bhatti S, Ali W. Does absenteeism affect academic performance among undergraduate medical students? Evidence from "Rashid Latif Medical College (RLMC). Advan Med Educ Pract. 2019;10:999-1008.

2. Dyrbye LN, Thomas MR, Shanafelt TD. Medical student distress: causes, consequences, and proposed solutions. Mayo Clinic Proc. 2005;80(12):1613-1622. doi:10.4065/80.12.1613.

3. Allen CW, Diamond-Myrsten S, Rollins LK. School absenteeism in children and adolescents. Am Fam Physician. 2018;98(12):738-744.

4. Brockfeld T, Müller B, de Laffolie J, Video versus live lecture courses: a comparative evaluation of lecture types and results. Med Educ Online. 2018;23(1):1555434... doi:10.1080/10872981.2018.1555434

Dove Medical Press encourages responsible, free and frank academic debate. The content of the Advances in Medical Education and Practice 'letters to the editor' section does not necessarily represent the views of Dove Medical Press, its officers, agents, employees, related entities or the Advances in Medical Education and Practice editors. While all reasonable steps have been taken to confirm the content of each letter, Dove Medical Press accepts no liability in respect of the content of any letter, nor is it responsible for the content and accuracy of any letter to the editor.

\section{Publish your work in this journal}

Advances in Medical Education and Practice is an international, peerreviewed, open access journal that aims to present and publish research on Medical Education covering medical, dental, nursing and allied health care professional education. The journal covers undergraduate education, postgraduate training and continuing medical education including emerging trends and innovative models linking education, research, and health care services. The manuscript management system is completely online and includes a very quick and fair peer-review system. Visit http://www.dovepress.com/testimonials.php to read real quotes from published authors. 